\title{
Phytoplankton community structure changes following simulated upwelled iron inputs in the Peru upwelling region
}

\author{
Clinton E. Hare ${ }^{1}$, Giacomo R. DiTullio ${ }^{2}$, Charles G. Trick ${ }^{3}$, Steven W. Wilhelm ${ }^{4}$ \\ Kenneth W. Bruland ${ }^{5}$, Eden L. Rue ${ }^{5}$, David A. Hutchins ${ }^{1, *}$ \\ ${ }^{1}$ College of Marine Studies, University of Delaware, 700 Pilottown Road, Lewes, Delaware 19958, USA \\ ${ }^{2}$ Hollings Marine Laboratory, University of Charleston, 205 Fort Johnson, Charleston, South Carolina 29412, USA \\ ${ }^{3}$ Department of Biology, University of Western Ontario, Biological and Geological Sciences Building, London, \\ Ontario N6A 5B7, Canada \\ ${ }^{4}$ Department of Microbiology, University of Tennessee, 1414 West Cumberland, Knoxville, Tennessee 37996, USA \\ ${ }^{5}$ Institute of Marine Sciences, University of California, Santa Cruz, 1156 High Street, Santa Cruz, California 95064, USA
}

\begin{abstract}
The effects of iron on phytoplankton community structure in 'High Nutrient Low Chlorophyll' regions of the ocean have been examined using both shipboard batch cultures (growouts) and open ocean mesoscale fertilization experiments. The addition of iron in these areas frequently results in a shift from communities dominated by small non-siliceous species towards ones dominated by larger diatoms. We used a new shipboard continuous culture experimental design in iron-limited Peru upwelling waters to examine shifts in phytoplankton structure and their biogeochemical consequences following simulated upwelled iron inputs. By allowing the added iron to pre-equilibrate with natural seawater ligands, we were able to supply iron in realistic chemical species at rates and concentrations similar to those found in upwelled waters off Peru. The community shifted strongly from cyanobacteria towards diatoms, and the extent of this shift was proportional to the increase in iron supply. Eukaryotic nanophytoplankton were the first to respond to the iron addition, followed by a community dominated by small pennate diatoms by Day 5 . These community changes led to increased biogenic silica:particulate organic nitrogen (BSi:PON) and biogenic silica:particulate organic carbon (BSi:POC) production ratios, driven mainly by increases in diatom numbers with increasing iron. Our experiment demonstrated both similarities to and differences with parallel growout experiments and previous mesoscale fertilization experiments, and suggest that the shipboard continuous culture method can be applied to questions that cannot be easily addressed by either of these previous iron addition techniques.
\end{abstract}

KEY WORDS: Shipboard chemostat · Continuous culture $\cdot$ Phytoplankton $\cdot$ Community composition · Peru upwelling $\cdot$ Iron limitation

\section{INTRODUCTION}

The micronutrient iron limits phytoplankton primary production rates in the High Nutrient Low Chlorophyll (HNLC) regimes of the world ocean. In most HNLC regions, including much of the Southern Ocean, the Equatorial Pacific, and coastal California and Peru, aeolian inputs are minimal and the major source of iron is through upwelling processes (Brand et al. 1991,
deBaar et al. 1995, Coale et al. 1996a, Landry et al. 1997, Bruland et al. 2001, 2005). Algal growth in these regions is supported through low level inputs of subsurface iron that are sustained and continuous, at least relative to the timescales of phytoplankton growth (days).

Iron limitation of phytoplankton in HNLC areas has been examined mainly by 2 methods: shipboard 'growout' bottle incubations (Martin \& Gordon 1988, 
de Baar et al. 1990, 1995, Martin et al. 1991, Price et al. 1991, Hutchins \& Bruland 1998, Hutchins et al. 2002) and mesoscale open ocean iron fertilization experiments (Martin et al. 1994, Coale et al. 1996a, 2004, Boyd et al. 2000, 2004). Both of these methods clearly indicate that phytoplankton production is limited by iron availability, but their ability to realistically evaluate the ecological and biogeochemical consequences of iron stress on these communities is limited. This is at least partly due to the inherent nature of the iron additions used by these 2 methods (Hutchins et al. 2003). Both growout and mesoscale fertilization experiments usually rely on initial inputs of iron at high concentrations (1 to $3 \mathrm{nM} \mathrm{Fe}$ ), levels that are typically 1 to 2 orders of magnitude higher than those that occur naturally in HNLC environments (0.02 to $0.1 \mathrm{nM}$, Martin \& Gordon 1988, Martin et al. 1990, Bruland et al. 1991, 2001, 2005).

Growout and mesoscale iron additions also cannot add $\mathrm{Fe}$ in the chemical form present under natural ambient conditions. Most of these experiments have used inorganic Fe-additions, typically ferrous sulfate or ferric chloride. In contrast, the iron available to phytoplankton in natural waters is very strongly complexed with natural organic ligands (Gledhill \& van den Berg 1994, Rue \& Bruland 1995, 1997, Wu \& Luther 1995). Previous experimental methods were unable to add iron pre-equilibrated with these natural ligands, raising questions of chemical speciation effects on growth and floristics.

Laboratory continuous culturing or chemostat systems allow algal biomass, growth rates and nutrient concentrations to reach steady-state, keeping the culture in exponential growth for extended periods. Harrison \& Davis (1979) were the first to use continuous culturing methods with natural phytoplankton communities, in shore-based outdoor mesocosms. Continuous culturing methods, both in the laboratory and onshore, have been used to examine shifts in natural phytoplankton communities or in competitive experiments between multiple species. These shifts have been observed in response to multiple factors, including nutrient supply mode (continuous versus pulsed, Turpin \& Harrison 1979, 1980, Turpin et al. 1981), major nutrient ratios (Titman 1976, 1977, Harrison \& Davis 1979), and dilution rates (Harrison \& Davis 1979, Mickelson et al. 1979, Turpin \& Harrison 1979, Thomas et al. 1980). Variations in all of these factors have been indicated as selective forces driving dominance shifts between or within phytoplankton groups (Harrison \& Turpin 1982).

While no chemostat work has been performed with Fe availability as a variable in natural communities, it was shown in the laboratory that altering the Fe concentration in continuous additions has a large effect on the physiological status of cyanobacteria (Trick \& Wil- helm 1995, Wilhelm \& Trick 1995). A few growout experiments have examined changes in natural phytoplankton communities across a range of iron concentrations (Coale et al. 1996b, Hutchins et al. 2002), but none to our knowledge have looked at variations in continuous inputs of iron in a natural community.

A new shipboard method described by Hutchins et al. (2003) adapted laboratory continuous culturing techniques for use with deck-board bottle incubations containing mixed natural algal assemblages at sea. The shipboard continuous culturing system has a unique advantage over current at sea methods in its ability to supply limiting nutrients at controlled input rates and concentrations. Continuous inputs of nutrients by this method have the potential to more realistically simulate the biogeochemical and biological effects of advective processes from below the mixed layer.

Coastal regions along eastern boundary currents have recently been added to the areas considered to be iron-limited. Studies off central California (Hutchins \& Bruland 1998, Hutchins et al. 1998, Johnson et al. 1999, Bruland et al. 2001, Firme et al. 2003) and more recently off Peru (Hutchins et al. 2002, Eldridge et al. 2004, Bruland et al. 2005) show that phytoplankton productivity can be limited by iron availability in certain coastal upwelling regions. The spatial and temporal patterns of coastal upwelling events can result in a mosaic of iron-replete and iron-deplete conditions that are closely tied to alternating active upwelling and relaxation events (Hutchins et al. 1998, 2002, Firme et al. 2003, Bruland et al. 2005) and the location of the upwelled parcel of water relative to continental shelf sedimentary iron sources (Johnson et al. 1999, Bruland et al. 2001, 2005).

The Peru upwelling region is one of the most productive regions in the world's ocean. Upwelling off Peru is a persistent year-round process, and iron inputs by fluvial and aeolian sources make only a minor contribution to these coastal waters (Bruland et al. 2005). As with most iron-limited areas in the ocean, the major source of iron is advection from below through upwelling of subsurface water that is high in nutrients. Bruland et al. (2005) reported that iron was found at high concentrations in high-chlorophyll 'brown' surface waters over the continental shelf along Peru, but quickly fell below potentially limiting concentrations within the 'blue water' regions off the shelf. Both spatial variability in iron concentrations in subsurface water (Bruland et al. 2005) and interannual variations in upwelling strength due to El Niño Southern Oscillation (ENSO) events (Codispoti et al. 1982, Johnson et al. 1999) are likely to have large impacts on the iron delivered to the surface waters in upwelling regions. Spatial variability in iron supply significantly impacts phytoplankton community assemblages with diatoms 
dominating ( $>90 \%$ of total biomass) in the high iron regions within the Peru upwelling regime (DiTullio et al. in press).

The aim of this study was not to carry out diagnostic experiments to show that phytoplankton within the Peru upwelling region could be iron-limited. This has already been reported with the use of deck-board growout incubations by Hutchins et al. (2002) and confirmed with similar methods by Eldridge et al. (2004). Instead, our goal was to examine changes in phytoplankton community structure and carbon and nutrient biogeochemistry when realistic concentrations of iron are added continuously over several days, simulating an upwelling event. The collected water and initial phytoplankton community used in this experiment were the same as those used for the growout experiment presented in Hutchins et al. (2002), allowing comparisons between established batch-type bottle incubations and the continuous addition incubation method used in this study.

The use of a trace metal clean version of a shipboard chemostat system modified from Hutchins et al. (2003) allowed us to simulate steady-state inputs at a range of iron concentrations, such as those that could be supplied by upwelling from varying depths or different parcels of subsurface water. Our study indicated that the slow, continuous addition of realistic iron levels pre-complexed to natural ligands resulted in major shifts in the phytoplankton community away from smaller prokaryotic algal species, and towards a larger and more heavily silicified eukaryotic community.

\section{MATERIALS AND METHODS}

Water collection. Surface seawater was collected on September 15, 2000, in off-shelf Peruvian coastal water at $9^{\circ} 39.0^{\prime} \mathrm{S}$ and $81^{\circ} 23.3^{\prime} \mathrm{W}$. The experiment was run in parallel with the 'Peru Upwelling' experiment reported in Hutchins et al. (2002). Sea surface water temperature and salinity were $18.3^{\circ} \mathrm{C}$ and $35.13 \mathrm{psu}$, respectively. Water was collected from approximately $10 \mathrm{~m}$ depth using a trace metal-clean Teflon pumping system (Hutchins et al. 2002, Bruland et al. 2005).

Experimental setup and Fe measurements. The shipboard continuous culture system used for this study was a trace metal clean version of that used by Hutchins et al. (2003) for nitrogen-addition experiments in the Sargasso Sea. All bottles and inflow lines used for the system were acid soaked with $10 \% \mathrm{HCl}$ for 2 mo using standard trace metal clean (TMC) techniques. The system was then rinsed by pumping low Fe seawater $(<0.1 \mathrm{nM}$, Bruland et al. 2005) for $8 \mathrm{~h}$ through the system at sea to remove any traces of acid from both the bottles and the inflow lines. Medium reservoirs consisted of $50 \mathrm{l}$ high density polyethylene (HDPE) carboys that were filled with $0.2 \mu \mathrm{m}$ filtered TMC collected seawater with initial total dissolved Fe concentration of $0.08 \mathrm{nM}$, each supplying a set of triplicate experimental bottles on deck through Teflon inflow supply tubing.

Dissolved $\mathrm{Fe}\left(\mathrm{FeCl}_{3}\right.$ in $\left.0.01 \mathrm{~N} \mathrm{HCl}\right)$ was added to the three $50 \mathrm{l}$ medium reservoirs (1 for each treatment) at a final total concentration of $0.8,1.3$, and $3.7 \mathrm{nM}$ (Table 1) as measured by cathodic stripping voltammetry (CSV) of UV-oxidized samples (Rue \& Bruland 1997, Bruland et al. 2005). These total dissolved iron concentrations correspond approximately to typical values at 20 to $100 \mathrm{~m}$ depth in subsurface waters off the shelf near this station (Bruland et al. 2005). These subsurface values increase in concentration over the broad shelf regions off northern and central Peru (Bruland et al. 2005).

A no-addition control was not used, as we intended to examine the relative effects of varying concentrations of subsurface iron inputs, rather than attempting a diagnostic evaluation of whether or not the system was ironlimited. A triplicate no-addition control treatment for diagnostic purposes was included in the parallel growout experiment using the same water collection presented by Hutchins et al. (2002). Iron complexation and labile iron concentrations in the medium reservoirs were determined at sea using competitive ligand CSV according to Rue \& Bruland (1997). 'Labile' iron denotes iron measured directly by electrochemistry that is presumed to represent free inorganic $\mathrm{Fe}$ species not bound to organic ligands.

Non-filtered TMC collected surface seawater with the plankton community was collected in an acidwashed $50 \mathrm{l}$ mixing carboy and dispensed into the modified $2.7 \mathrm{l}$ polycarbonate incubation bottles (Hutchins et al. 2003). Bottles were incubated in spectrally corrected blue deck-board flow-through incubators at surface seawater temperature at $40 \%$ of ambient light. Iron added to seawater medium in reservoirs was allowed to equilibrate for $\sim 8 \mathrm{~h}$ before pumping

Table 1. Concentration of total dissolved iron and labile iron (uncomplexed) on Day 3 in the medium reservoirs. Labile iron concentration was determined using electrochemical analysis (cathodic stripping voltammetry, CSV) and is assumed to be a function of the iron not bound to natural organic ligands

\begin{tabular}{|lccc|}
\hline Treatment & Low & Medium & High \\
\hline Total dissolved Fe $(\mathrm{nM})$ & 0.8 & 1.3 & 3.7 \\
Labile Fe (nM) & $<0.05$ & 0.06 & 0.08 \\
Total dissolved Fe & $>94$ & 95 & 98 \\
$\quad$ complexed by & & & \\
natural ligands (\%) & & & \\
\hline
\end{tabular}


was started. Medium was supplied at a rate of $1.72 \mathrm{ml}$ $\mathrm{min}^{-1}$, setting the doubling rate of the community at approximately $1 \mathrm{~d}^{-1}(\mu=0.69)$. Incubation bottles were manually shaken every $1.5 \mathrm{~h}$ to prevent the settling of large cells and to facilitate their removal through the outflow. Sampling was performed at sunset by turning the inflow rate to maximum for approximately $90 \mathrm{~min}$ and collecting $\sim 200 \mathrm{ml}$ samples $(<10 \%$ of total bottle volume) through the outflows. Inflow was turned off following sampling for approximately $2 \mathrm{~h}$ to correct for excess dilution from the higher flow rate during sample collection. All sample analytical values were corrected for dilution during collection except the final day, when samples were taken directly from incubation bottles. Statistics were performed using a 1-way or 2-way fixed repeated measures ANOVA (Microsoft Excel and SPSS) test for significance between treatments for all measured parameters.

Dissolved and particulate nutrients. Daily measurements were made for dissolved nutrients (nitrate plus nitrite, orthophosphate, and silicic acid) on $0.2 \mu \mathrm{m}$ filtered samples at sea using a Lachat Quick Chem autoanalyzer as described in Bruland et al. (2005). Water samples for particulate organic carbon (POC) and nitrogen (PON) were filtered on combusted $13 \mathrm{~mm} \mathrm{A/E}$ filters (Gelman) and immediately dried at sea. POC and PON were measured in the laboratory using a Carlo-Erba CHN analyzer (Hutchins et al. 1998). Biogenic silica (BSi) was filtered at sea onto $0.6 \mu \mathrm{m} 47 \mathrm{~mm}$ polycarbonate filters and dried at sea. Samples were analyzed in the laboratory using the methods of Brzezinski \& Nelson (1995).

Plankton community structure and photosynthetic efficiency. Samples were measured daily at the same time each day for changes in PSII photosynthetic efficiency (variable fluorescence over maximum fluorescence, $F_{\mathrm{v}} / F_{\mathrm{m}}$ ) using fast repetition rate fluorometry (FRRF), (Behrenfeld \& Falkowski 1999). All samples were dark adapted for 30 min before analysis and run within $1 \mathrm{~h}$ of sampling. FRRF settings used for analysis of these samples are described elsewhere (Riseman \& DiTullio 2004). Phytoplankton community structure was examined using multiple methods on triplicate samples. Size-fractionated chlorophyll a (chl a) was performed daily to monitor overall changes in community size structure. Samples were filtered onto GF/F (Whatman, total chl a) and $5.0 \mu \mathrm{m} 47 \mathrm{~mm}$ polycarbonate filters (Millipore, $>5.0 \mu \mathrm{m}$ size class) and extracted in $90 \%$ acetone in the freezer for $24 \mathrm{~h}$ before analysis at sea on a Turner AU10 fluorometer using a nonacidification protocol (Welschmeyer 1994).

Daily samples were counted using a Becton Dickinson FACSCalibur flow cytometer on live samples as described by Hutchins et al. (2002). General groups of algae enumerated were defined to be large eukaryotic cells $(>5 \mu \mathrm{m})$, smaller eukaryotic nanoplankton (2 to $5 \mu \mathrm{m}$, both red fluorescing), and 2 small prokaryotic picophytoplankton groups defined as Synechococcus and Prochlorococcus, fluorescing yellow and red respectively (Frankel et al. 1990, Durand \& Olson 1996, Campbell 2001). Bacterial and viral samples were preserved daily in glutaraldehyde and stored at $4^{\circ} \mathrm{C}$ for analysis in the laboratory. The abundance of viruses and bacteria in samples was determined in the laboratory by staining samples with either SYBR Green I (Noble \& Fuhrman 1998) or Acridine Orange (Hobbie et al. 1977) prior to direct enumeration by epifluorescence microscopy.

Microscopic phytoplankton cell counts (50 ml) were preserved on the final day in $2 \%$ glutaraldehyde (Hutchins et al. 1998, 2001). Phytoplankton samples were concentrated by low-pressure filtration using $0.2 \mu \mathrm{m}$ filters and resuspended in $1 \mathrm{ml}$ filtered seawater. Phytoplankton counts were determined by the average of counts from 10 fields on a $2 \mathrm{~mm}$ hemocytometer using a Zeiss Standard 25 microscope under epifluorescence.

Taxon-specific photosynthetic accessory pigments were analyzed on the initial and final days using high performance liquid chromatography (HPLC) to determine major phytoplankton group abundances (DiTullio et al. 2003). One liter samples were vacuum-filtered onto $25 \mathrm{~mm} \mathrm{GF} / \mathrm{F}$ filters and frozen immediately in liquid nitrogen until analysis. Samples were extracted in $90 \%$ acetone and analyzed using a HP 1050 HPLC system equipped with autosampler, diode array (DAD) and fluorescence detectors. The gradient elution program utilized was a modification of the Zapata et al. (2000) method. Complete details of the HPLC method are described elsewhere (DiTullio \& Geesey 2002). Phaeophorbide concentrations were determined as the sum of all phaeopigment peaks as measured using the $406 \mathrm{~nm}$ absorbance channel on the DAD.

\section{RESULTS}

Iron was added to $0.2 \mu \mathrm{m}$ trace TMC filtered seawater in the medium reservoirs at concentrations of $0.8,1.3$, and $3.7 \mathrm{nM}$ total dissolved Fe. The added iron was allowed to complex with the natural ligands present in the seawater for approximately $8 \mathrm{~h}$ before the start of the experiment, giving final labile (uncomplexed) iron concentrations for each treatment of $<0.05,0.06$, and $0.08 \mathrm{nM}$ (Table 1 ). Thus $>94$ to $98 \%$ of total dissolved Fe in these 3 treatments was complexed to natural ligands in the reservoirs used to supply the culture bottles.

Initial total chl a concentration in the collected water was approximately $1 \mu \mathrm{g} \mathrm{l}^{-1}$. Total chl a remained relatively constant throughout most of the experiment in the 
2 highest iron treatments, ranging between 0.5 and $1.5 \mathrm{\mu g} \mathrm{l}^{-1}$ (Fig. 1A). In the lowest Fe-addition, however, chl a decreased steadily to $\sim 0.3 \mu \mathrm{g} \mathrm{l^{-1 }}$ by Day 4 . Chl $a$ in all 3 treatments was significantly different by Day 4 ( $\mathrm{p}<$ $0.05)$, but the 2 highest treatments were not significantly different from each other on Day $5(\mathrm{p}<0.05)$. If we assume that grazing rates were similar in the 3 iron treatments, then the lowest iron treatment total chl a concentration suggested that cells were being washed out due to growth rates being lower than the dilution rate.

The concentration of $>5 \mu \mathrm{m}$ chl a remained constant throughout the experiment and was not significantly different in any of the treatments until Day 4. After this point, the $0.8 \mathrm{nM}$ treatment had significantly lower values than the 2 higher iron treatments $(p<0.05$, Fig. 1B). Due to the small increase in the $>5 \mu \mathrm{m}$ fraction compared to the total chl a fraction in the higher iron treatments, however, the percentage of the total chl $a$ in the $>5 \mu \mathrm{m}$ fraction on Day 5 was $50 \%$ in the lowest Fe treatment but only $\sim 30 \%$ in the other 2 higher Fe treatments.
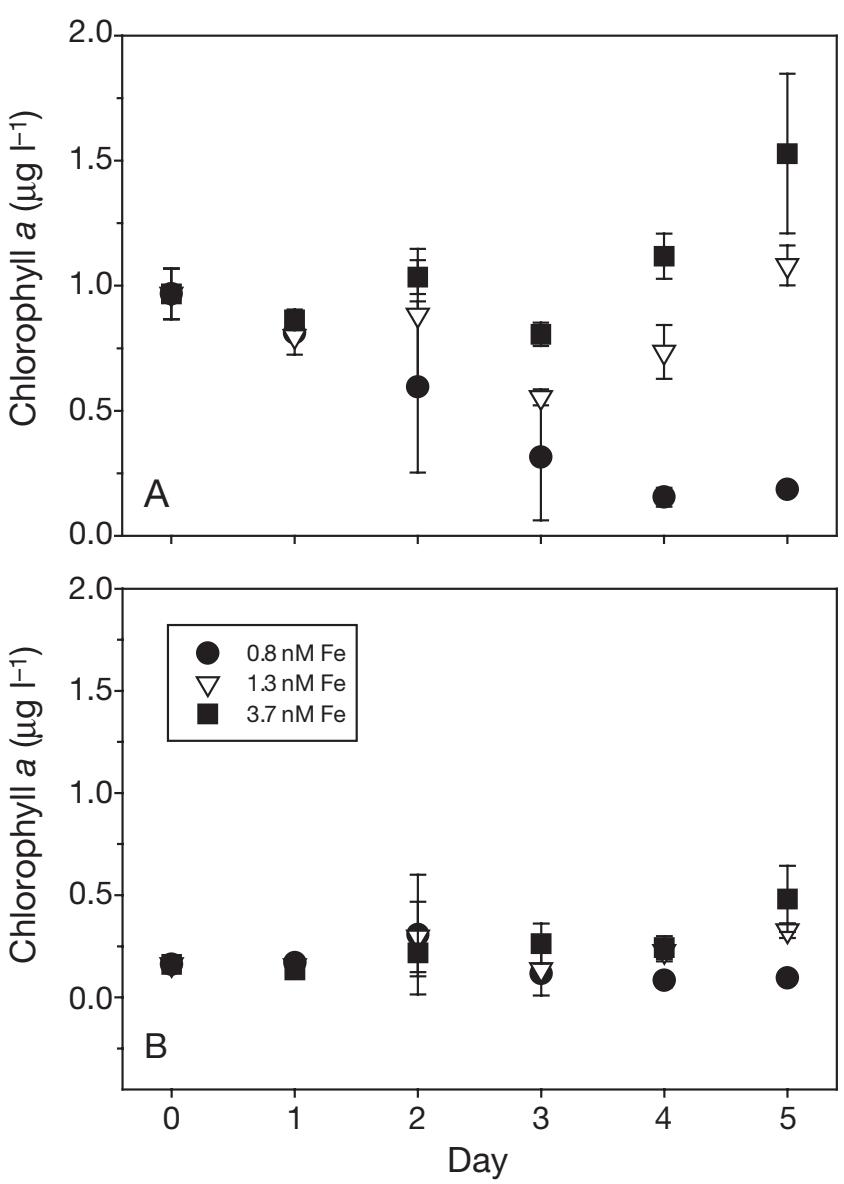

Fig. 1. Daily chl a concentrations $\left(\mu \mathrm{g} \mathrm{l}^{-1}\right)$ determined by shipboard fluorometry for (A) total chl a (GF/F) and (B) the $>5 \mu \mathrm{m}$ size class. Symbols and error bars represent mean \pm SD of triplicate incubation bottle under continuous addition of $\mathrm{Fe}$
Initial major nutrients in the seawater sampled were 16.4 $\mathrm{\mu M}$ nitrate plus nitrite (referred to as $\mathrm{NO}_{3}{ }^{-}$), $1.2 \mu \mathrm{M}$ phosphate $\left(\mathrm{PO}_{4}{ }^{3-}\right)$, and $7.8 \mu \mathrm{M}$ silicic acid $\left(\mathrm{Si}(\mathrm{OH})_{4}\right)$. Major dissolved nutrients initially decreased during the first $2 \mathrm{~d}$ before, reaching relatively steady levels from Day 2 to Day 4 (Fig. 2). On Day 5, all dissolved nutrients increased slightly in all treatments. Major nutrients were never depleted or limiting throughout the experiment $\left(\mathrm{NO}_{3}{ }^{-}>8 \mu \mathrm{M}, \mathrm{PO}_{4}{ }^{3-}>0.5 \mu \mathrm{M}, \mathrm{Si}(\mathrm{OH})_{4}>5 \mu \mathrm{M}\right)$, suggesting that iron being added to the inflow medium was the limiting nutrient for phytoplankton growth.

Photosynthetic efficiency of PSII $\left(F_{\mathrm{v}} / F_{\mathrm{m}}\right)$, an indicator of algal Fe-limitation, initially increased in all treat-
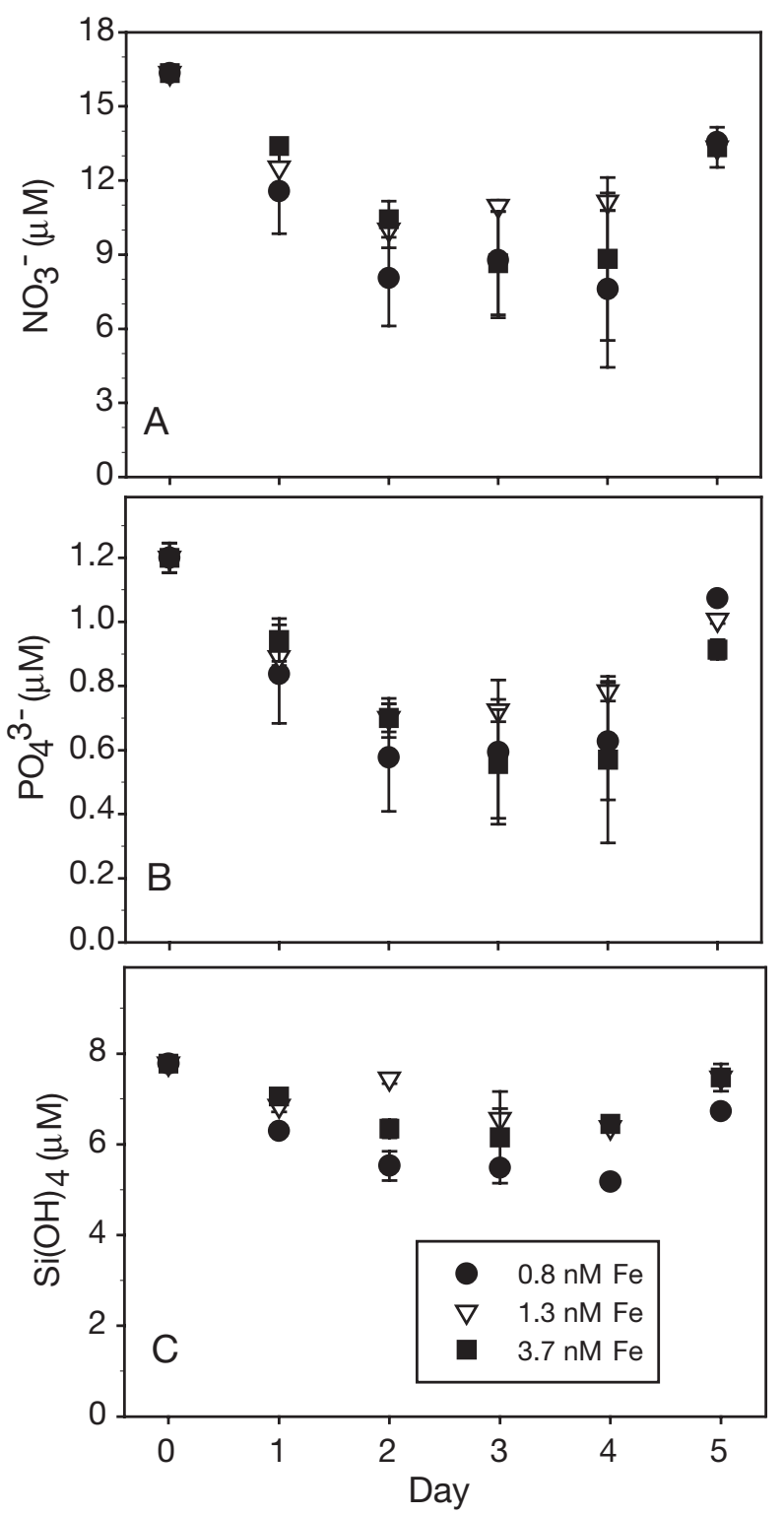

Fig. 2. Major dissolved nutrient concentrations $(\mu \mathrm{M})$ for the $3 \mathrm{Fe}$ addition treatments. (A) Nitrate, (B) phosphate, and (C) silicic acid. Symbols and error bars as in Fig. 1 
ments from 0.27 to $\sim 0.35$ (Fig. 3). Photosynthetic efficiency in the lowest iron treatment was significantly lower $(\mathrm{p}<0.001)$ than in the 2 higher iron treatments after Day 2. In the 2 highest iron treatments $F_{\mathrm{v}} / F_{\mathrm{m}}$ remained relatively constant (0.30 to 0.35 ) from Day 1 to Day 3, and increased slightly on the final 2 days. These high iron samples reached a maximum value of 0.40 on Day 5 , and were not significantly different $(p>$ 0.05 ) from each other. Photosynthetic efficiencies were clearly related to iron input concentrations, though $F_{\mathrm{v}} / F_{\mathrm{m}}$ never approached the theoretical maximum level (0.65) sometimes seen in Fe-replete incubations (Kolber et al. 1998) or observed in the 'brown water' regions off Peru (Bruland et al. 2005).

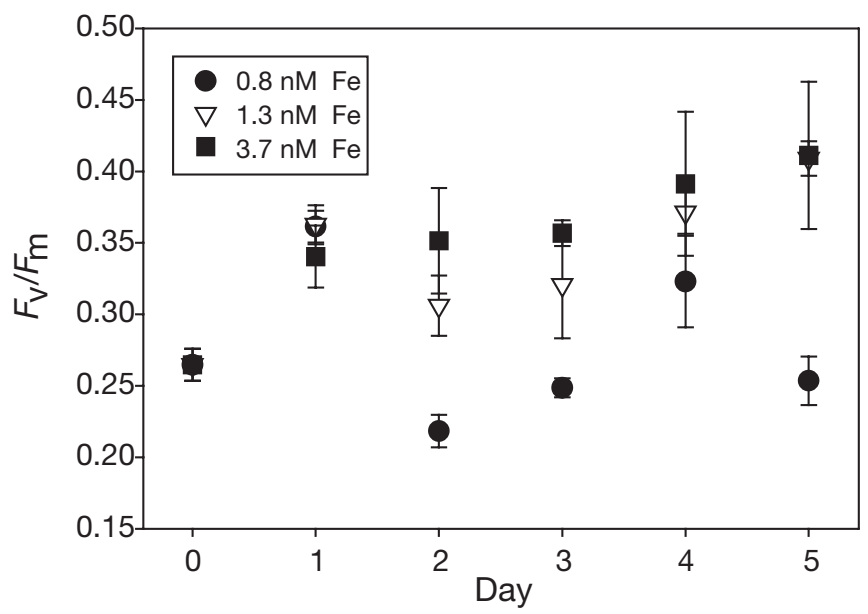

Fig. 3. Photosynthetic efficiency of photosystem II, variable fluorescence over maximum fluorescence $\left(F_{\mathrm{v}} / F_{\mathrm{m}}\right)$, as determined by fast repetition rate fluorometry. Symbols and error bars as in Fig. 1

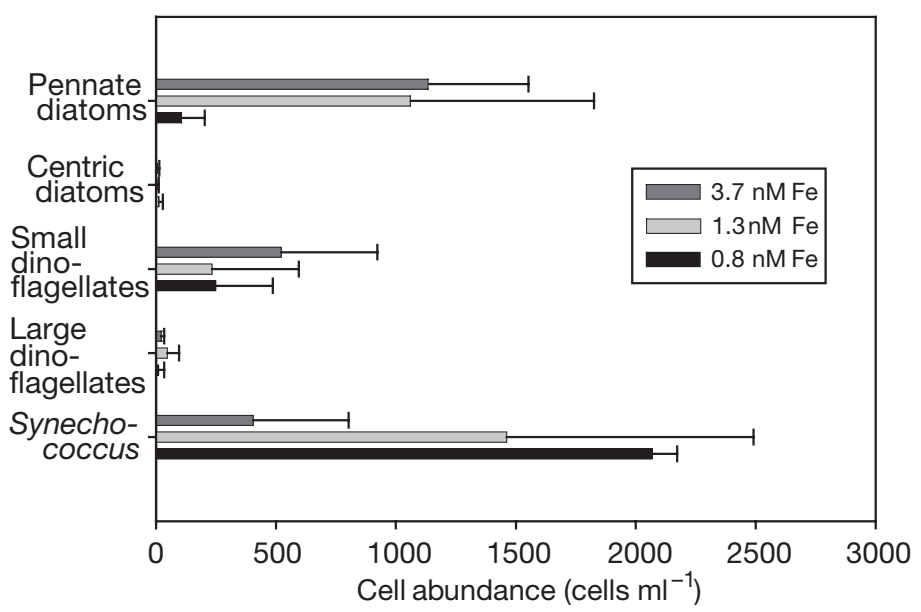

Fig. 4. Microscopic cell counts of major phytoplankton groups at the final timepoint including pennate diatoms, centric diatoms, small dinoflagellates, large dinoflagellates, and Synechococcus. Bars and error bars represent mean + SD of triplicate bottles
Microscopic cell counts indicated major shifts in community structure of dominant phytoplankton groups with increasing inputs of iron (Fig. 4). Synechococcus abundance decreased with increasing iron input rates, but only the lowest Fe treatment and the highest treatment were significantly different from each other $(p<0.05)$. Synechococcus abundance for the $1.3 \mathrm{nM}$ Fe treatment was not significantly different from either of the other 2 treatments $(p>0.05)$, due to large variations between replicate bottles. Both small and large dinoflagellates did not differ significantly between any of the treatments on Day 5 ( p > 0.05, Fig. 4), though small dinoflagellates appeared to increase with increasing Fe supply. The diatom community was dominated by a single species of pennate diatom, Navicula sp. (apical length 15 to $30 \mu \mathrm{m}$, transapical width 3 to $5 \mu \mathrm{m}$ ), with few centric diatoms present. Navicula sp. abundances were significantly different on Day 5 between the highest and lowest Fe treatments $(\mathrm{p}<0.05$, Fig. 4$)$.

Total bacterial concentrations increased slightly from the initial abundance of $2.5 \times 10^{5} \mathrm{cells} \mathrm{ml}^{-1}$ to approximately $6 \times 10^{5}$ cells $\mathrm{ml}^{-1}$ in all treatments by Day 2 (not shown). On Day 4 all treatments increased by an order of magnitude to approximately $3 \times 10^{6}$ cells $\mathrm{ml}^{-1}$. There was no significant difference between any of the treatments throughout the 5 days. Viral abundance remained relatively constant around the initial concentrations of $1.4 \times 10^{8}$ virus-like particles $\mathrm{ml}^{-1}$ throughout the 5 days.

Taxon-specific photosynthetic accessory pigments for major phytoplankton groups were significantly different between the initial community and all Day 5 Fe-addition treatments ( $p<0.05$, Fig. 5A). There was about a 2-fold decrease in chl $b$ (chlorophytes and prochlorophytes) in all treatments from the initial concentration. Divinyl chl a (prochlorophytes), initially the second most abundant pigment concentration at $450 \mathrm{ng} \mathrm{l}^{-1}$, disappeared completely in all treatments by Day 5. Zeaxanthin (all cyanobacteria), initially the most prevalent pigment at $>550 \mathrm{ng} \mathrm{l}^{-1}$, declined dramatically in all 3 treatments but was not significantly different in any treatment on Day 5 ( $p>0.05)$. Autotrophic dinoflagellates (peridinin) disappeared completely in all treatments by Day 5 .

Alloxanthin (cryptophytes) and 19-butanoyloxyfucoxanthin (19-But, pelagophytes) increased slightly but significantly in all 3 treatments compared to their initial concentration $(p<0.05)$, but pelagophytes were only significantly different on Day 5 between the lowest and middle Fe treatments ( $p<0.05$, Fig. 5A). In all 3 Fe-addition treatments, the concentration of 19-hexanoyloxyfucoanthin (19-Hex, prymnesiophytes) and fucoxanthin (primarily diatoms) increased significantly by Day 5 over the initial value $(p<0.01)$. For both 


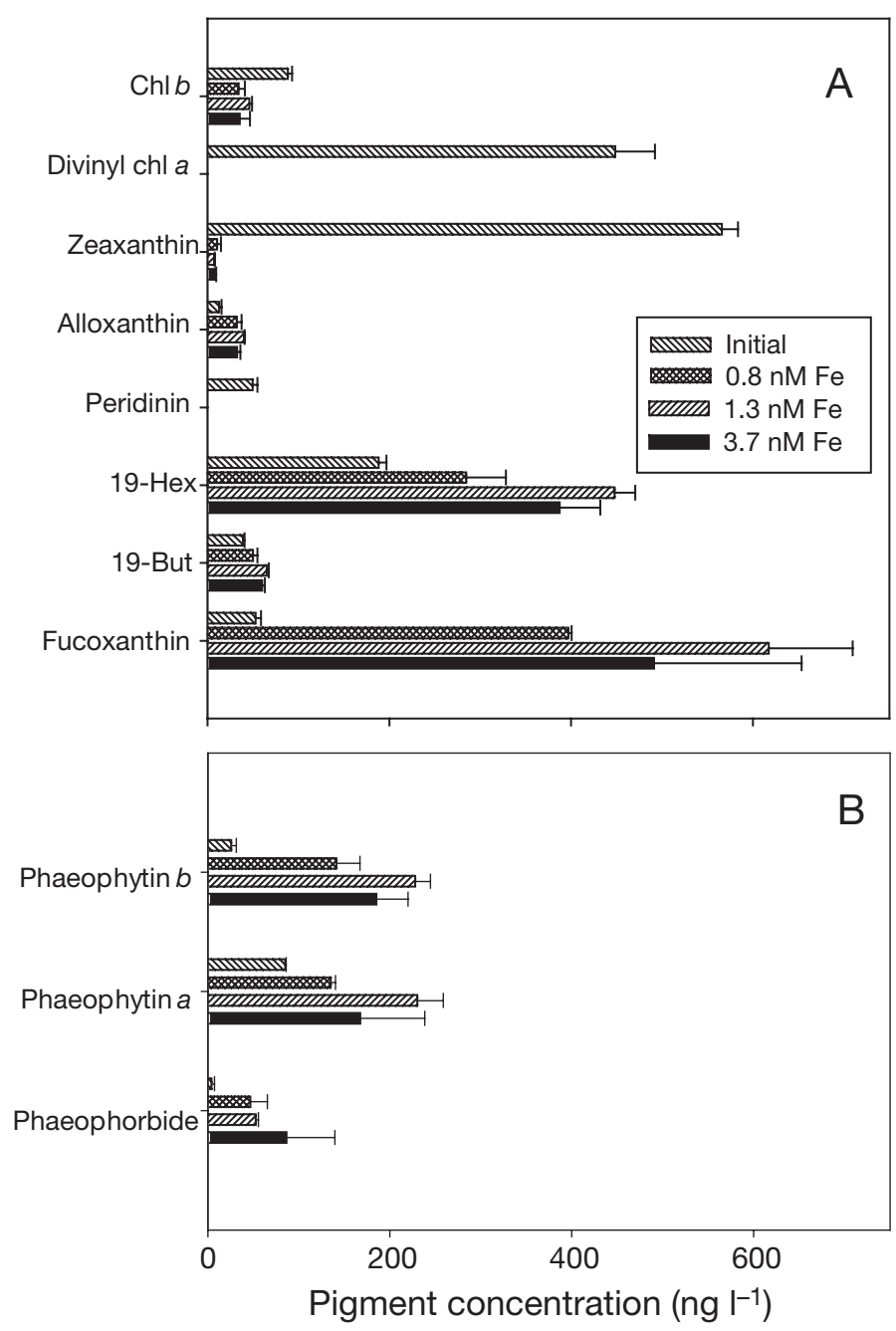

Fig. 5. (A) Taxon-specific phytoplankton pigments and (B) phaeopigment concentrations determined by high performance liquid chromatography (HPLC) $\left(\mathrm{ng} \mathrm{l}^{-1}\right)$. 19-But: 19-butanoyloxyfucoxanthin; 19-Hex: 19-hexanoyloxyfucoxanthin. Bars and error bars represent mean $+\mathrm{SD}$ of triplicate bottles

prymnesiophytes (19-Hex) and diatoms (fucoxantin) there was a significant difference between the middle and lowest Fe treatments $(\mathrm{p}<0.05)$, but neither was significantly different from the highest treatment $(\mathrm{p}>$ $0.05)$. The largest increase in any pigment concentration was fucoxanthin, which increased in all 3 treatments by about 10 -fold from an initial concentration of approximately $50 \mathrm{ng} \mathrm{l}^{-1}$. The largest decrease was seen in the cyanobacteria pigment concentrations (divinyl chl $a$ and zeaxanthin).

Phaeopigments are breakdown products of chl $a_{\text {, }}$ typically assumed to be related to grazing (Strom et al. 1998). Significant increases compared to the initial concentrations for all 3 phaeopigments measured were seen in the lowest and middle Fe treatments $(p<0.05)$, but only phaeophytin $b$ increased in the highest iron treatment ( $p<0.01$, Fig. 5B). Phaeophytin $a$ and phaeophytin $b$ concentrations in the $0.8 \mathrm{nM}$ Fe treatment were significantly lower than in the $1.3 \mathrm{nM}$ Fe treatment $(\mathrm{p}<0.05)$, while the $3.7 \mathrm{nM} \mathrm{Fe}$ treatment was not significantly different from either. There was no significant difference in the concentrations of the sum of all phaeophorbide peaks in all treatments on Day 5 $(\mathrm{p}>0.05)$.

Flow cytometry cell counts also revealed a pattern of response to Fe-additions. Cyanobacteria were the dominant group in the initial community (Fig. 6C).
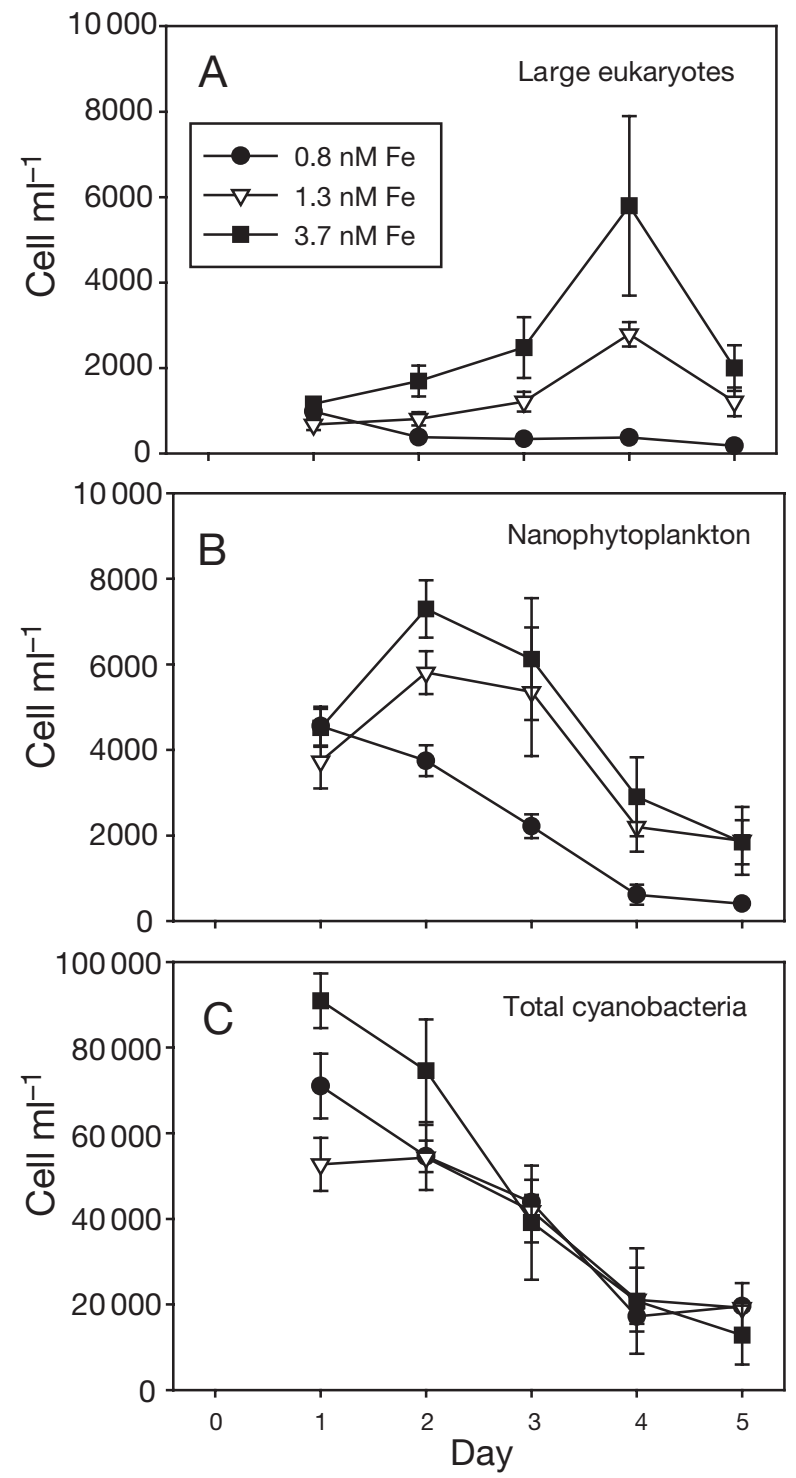

Fig. 6. Cell abundance of major phytoplankton groups as a percentage of total community chl $a$, determined by shipboard flow cytometry. The community was separated into 3 major classes based on size and fluorescence including (A) large eukaryotes, (B) nanophytoplankton, and (C) cyanobacteria. Symbols and error bars as in Fig. 1 
Nanophytoplankton tended to peak on Days 2 and 3 (Fig. 6B), followed by larger eukaryotes on Days 3 and 4 (Fig. 6A). Total cyanobacteria numbers decreased steadily in all treatments throughout the experiment (Fig. 6C). A similar trend was seen in both Synechococcus and Prochlorococcus abundance when examined individually (data not shown). These losses of prokaryotes in all treatments could have been partly due to containment artifacts, although microscopic counts also showed a treatment effect in the form of an inverse relationship between Synechococcus abundance and iron supply (Fig. 4).

Eukaryotic nanophytoplankton in the 2 higher iron treatments initially increased, followed by a steady decrease after Day 2, but remained significantly higher than in the low Fe treatment $(\mathrm{p}<0.001)$. Both nanophytoplankton and large eukaryotic phytoplankton decreased in the $0.8 \mathrm{nM}$ Fe treatment after Day 1, similar to the pattern seen in chl a concentration, possibly due to cell 'washout'. Large eukaryotes increased throughout the first $4 \mathrm{~d}$ in the 2 highest iron treatments, but decreased on Day 5. All treatments were significantly different from each other from Day 2 through Day 5 ( $\mathrm{p}<0.001$ ) with increasing abundance correlated with increasing iron concentration.

Mean cell size determined by flow cytometry (relative units) was significantly larger in the $0.8 \mathrm{nM} \mathrm{Fe}$ treatment than in the 2 higher Fe treatments after

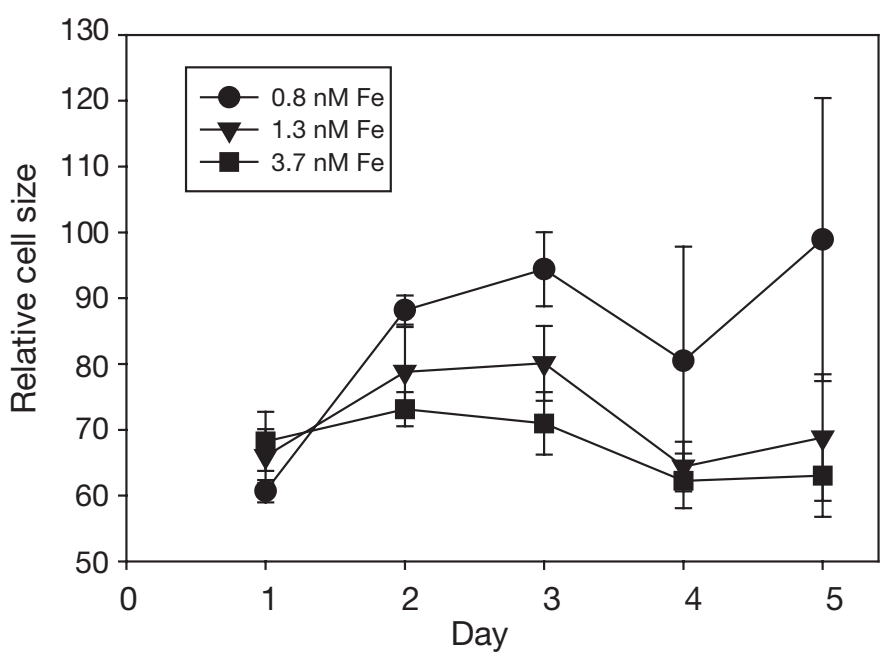

Fig. 7. Daily relative mean cell size for nanophytoplankton determined by flow cytometry. Symbols and error bars as in Fig. 1
Day 3 for nanophytoplankton ( $p<0.01$, Fig. 7). Relative cell size in the $1.3 \mathrm{nM}$ Fe treatment did not significantly differ from either of the other treatments. Relative cell sizes for large eukaryotes Synechococcus and Prochlorococcus were not significantly different between treatments, though prokaryotes also tended towards smaller cell size with increasing total dissolved Fe concentrations (data not shown).

POC, PON and BSi all increased with increasing Fe concentrations (Table 2). POC and PON in the $0.8 \mathrm{nM}$ Fe treatment decreased from the initial concentration, but increased in the 2 higher treatments. BSi levels increased in all treatments with increasing $\mathrm{Fe}$ above the initial BSi concentration, but were only significantly higher in the 2 highest Fe-additions $(p<0.01)$.

The changes in the elemental ratios of POC:PON, BSi:PON, and BSi:POC were examined relative to increasing continuous additions of iron (Table 2). The elemental POC:PON ratio did not change significantly from the initial value of 11.6 in any treatments ( $p>0.05$ ), but was significantly higher in the highest Fe treatment compared to the other 2 lower Fe treatments $(\mathrm{p}<0.05)$. BSi:PON and BSi:POC ratios significantly increased from initial values of 0.21 and 0.018 to as high as 0.94 and 0.095 , respectively, in the highest Fe treatment $(p<0.001)$. The increases in these ratios were mainly driven by the large increases in the BSi concentration with increasing Fe. Particulate nutrient ratios were also calculated as production ratios for both BSi:PON and BSi:POC (Table 2). There was negative production in these ratios in the $0.8 \mathrm{nM}$ Fe treatment, but these production ratios increased for both BSi:PON and BSi:POC with increasing $\mathrm{Fe}$ concentration in the 2 highest Fe treatments. The ratio of BSi:pennate diatom cells counted decreased 2-fold in the 1.3 and 3.7 nM Fe treatments $(0.45$ and $0.67 \mathrm{pmol} \mathrm{cell}^{-1}$ ) compared to the lowest Fe treatment (1.38 pmol cell $\left.{ }^{-1}\right)$. 


\section{DISCUSSION}

Dissolved iron in the ocean is $99 \%$ complexed to natural organic ligands (Gledhill \& van de Berg 1994, Rue \& Bruland 1995, Wu \& Luther 1995). Large discrete inputs during on deck growout experiments provide a source of iron to phytoplankton that they would be unlikely to encounter in the natural environment, with the majority of iron remaining in the dissolved fraction even at the end of the experiment (50 to $90 \%$, Takeda \& Obata 1995). The chemical speciation and availability of iron can influence species composition (Bruland et al. 1991) and iron bioavailability to both prokaryotic and eukaryotic phytoplankton (Hutchins et al. 1999a,b). Wells (2003) suggested that even repeated infusions of iron, as in many mesoscale iron fertilization experiments, might not convert excess macronutrients into diatom biomass due to strong complexing ligands in the natural environment. Wells (2003) also suggested that smaller continuous iron enhancements might increase the efficiency of diatom response by providing a low continuous source of bioavailable iron.

Continuous inputs from our seagoing culture system allow bottle experiments to be provided with dissolved iron that is complexed with the natural ligands present in the seawater collected with the initial community. While we did not measure the original levels of organic ligands in the collected filtered seawater, we did measure the fraction of iron that was bound to organic ligands in the medium reservoirs after the experiment was started. In this experiment 94 to $98 \%$ of total dissolved iron added (0.8 to $3.7 \mathrm{nM}$ ) was complexed with natural ligands, providing a narrow picomolar range of labile (uncomplexed) $\mathrm{Fe}$ of 0.05 to $0.08 \mathrm{nM}$. While some organic ligands can be produced during cell growth after Fe-addition and by release of organic material through either death or exudation, the organic ligand concentrations in natural seawater in unperturbed systems nearly always exceed the ambient concentration of dissolved Fe (Rue \& Bruland 1995). These 'excess ligands' available in the collected seawater were presumably available to bind to the Fe we added into our reservoirs. This unique feature of the continuous input method more closely simulates the natural speciation of iron in the environment (Rue \& Bruland 1995).

In this study our focus was on comparing relative iron input levels, from low to high. We assumed that a no-addition control was not an environmentally realistic treatment in a simulated upwelling event, so a noaddition control was not performed other than the diagnostic control included in the parallel growout (Hutchins et al. 2002). Since subsurface iron concentrations in Peru are always higher than surface Fe concentrations (Bruland et al. 2005), the main question is to what degree and at what concentrations new Fe is brought up by upwelling. A no-Fe control could, however, be beneficial to examine certain aspects of the phytoplankton response, such as possible selection for particular phytoplankton groups due to the dilution rate chosen. Within the experimental design the additional control treatment would have forced us to sacrifice one of the 3 iron treatments. This would have greatly reduced the amount of information we could obtain about variations over an ecologically realistic range of iron concentrations. The choice we made was to run a prognostic (rather than a diagnostic) Fe limitation experiment.

Turpin \& Harrison (1979) found that dilution rate is itself a powerful parameter in determining final community composition in natural community continuous culture experiments. By choosing a single dilution rate for this study, we were selecting for a community that was able to grow at or above this rate. Likewise, when nutrients are added in pulsed additions, the outcome can be quite different than when they are added in a continuous fashion (Turpin \& Harrison 1979, 1980). One must assume that the composition of the final assemblage would be different under different dilution regimes, based on these previous studies. For this study, we chose a dilution rate of 1 doubling $d^{-1}$ as a realistic estimate of growth rates in a highly productive tropical upwelling area.

Our short shipboard continuous culturing experiment never allowed our phytoplankton population to reach true steady-state for nutrients or total chl $a$, due to the time constraints on running this experiment at sea. Despite this, total chl $a$ and dissolved inorganic nutrients were fairly stable within a narrow range when compared to the large increases in biomass and drawdown of nutrients seen during the parallel growout experiments (Hutchins et al. 2002). In the parallel growouts chl a increased 6 to 8 times, while in this study chl a ranged from 0.5 to 1.5 times the initial values. In the high Fe treatment in the parallel growout (2.5 nM total dissolved Fe, Hutchins et al. 2002), final algal accessory pigment concentrations were $\sim 4$ times higher and cell densities and POC were 10 times higher than in the high Fe treatment used in this study ( $3.7 \mathrm{nM}$ total dissolved Fe). This is the result of losses through the outflow in this experiment, while there are no equivalent loss terms included in growout type experiments.

Growout experiments are similar to a laboratory batch culture (Hutchins et al. 2003). Major dissolved nutrients are drawn down until one becomes limiting or inhibitory by-products accumulate, causing the bloom to crash. In the parallel growout, nitrate was virtually depleted by Day 4 in the high iron treatment, whereas in the continuous culture system none of the 
major nutrients ever became limiting. This suggests that Fe probably remained the limiting nutrient in all treatments in this study. Even though true steady-state was not achieved in this experiment, we suggest that these experiments may accurately reflect the initial responses of an iron-limited algal community to transient Fe inputs during a $5 \mathrm{~d}$ upwelling event.

The photosynthetic efficiency $\left(F_{\mathrm{v}} / F_{\mathrm{m}}\right)$ of the community was similar to that of the parallel growouts by Hutchins et al. (2002) and Eldridge et al. (2004, BIO-6), ranging from 0.2 in the controls up to $0.4-0.45$ in the highest Fe-additions. These values are still well below the optimal value of iron-replete conditions $(0.65$, Kolber et al. 1998) and mesoscale fertilizations (0.5, Behrenfeld et al. 1996; 0.64, Boyd et al. 2000) or observed in the 'brown water' regions of the Peru upwelling regime (0.65, Bruland et al. 2005). This suggests that both in this experiment and in the growout experiments the community was still under iron stress even at the higher iron values. It is also possible that lack of another major or micronutrient could have affected $F_{\mathrm{v}} / F_{\mathrm{m}}$. However, no macronutrient was depleted at any time during the experiments to levels that would typically be considered limiting. Another possibility is that different groups of phytoplankton may have different optimal photosynthetic efficiencies. The dominant communities in this experiment and the growout experiments were not the large centric diatoms that are commonly dominant in the "brown water' regions of the Peru upwelling regime, and could have an intrinsically lower maximum $F_{\mathrm{v}} / F_{\mathrm{m}}$.

Our experiment indicated that increasing continuous inputs of dissolved iron resulted in a progressive shift in algal community structure from small prokaryotic cyanobacteria towards larger species. In this experiment, the pennate diatom Navicula sp. dominated numerically in the final communities at the 2 higher iron levels. During the parallel growout experiments, the dominant diatom was also a pennate species but it was a Pseudo-nitzschia species (Hutchins et al. 2002). The Navicula species was slightly larger (15 to $30 \mu \mathrm{m})$ than the Pseudo-nitzschia species (10 to $20 \mu \mathrm{m})$. This Pseudo-nitzschia species identified by Hutchins et al. (2002) in the growout experiments is fairly small for this genus. Direct visual comparison of phytoplankton samples from this experiment and the parallel growouts confirmed that different pennate diatom species became dominant in the 2 studies using different Fe-addition methods. Pennate diatoms have been the primary diatom group that blooms during most iron enrichment experiments (Martin et al. 1991, Price et al. 1991, Cavender-Bares et al. 1999, Boyd et al. 2000, Gervais et al. 2002, Hutchins et al. 2002, Coale et al. 2004). However, in growouts off coastal California (Hutchins et al. 1998) and during the Subarctic Pacific
Iron Experiment for Ecosystems Dynamics Study (SEEDS) mesoscale enrichment in the western subarctic Pacific (Tsuda et al. 2003), centric diatoms were the dominant group.

The genus Navicula comprises both benthic and pelagic species, and these have been found as components of algal communities in many upwelling regimes (Estrada \& Blasco 1979, Blasco et al. 1980, de Mendiola 1981, Hutchins et al. 1998). It is possible that the presence of Navicula in this study may have been due to cells that were suspended from the sediments during upwelling and carried offshore to our sampling site. However, sampling occurred offshore in deeper waters, where the presence of benthic species in the pelagic zone would seem to be unlikely.

If present, a benthic species could potentially have an advantage over free-living pelagic diatom species in an enclosed experiment. No wall growth was observed in this experiment, and the frequent vigorous shaking of the bottles would likely prevent any cells from rapidly colonizing the sides of the bottles. Regardless of the source of the Navicula sp. that dominated in our experiment, it is notable that different species of small pennate diatoms grew in this study and in the parallel growout study despite both having the same possible bottle artifacts. This strongly suggests that diatom species composition was affected by the different modes of nutrient additions in the 2 experiments.

To gain a sense of changes in the community through time, we relied on daily flow cytometry counts from within the incubation bottles for this experiment. Like any continuous culture system, daily sampling of the bottles needs to be limited to avoid excessive disturbance to the system. Other community composition analyses such as photosynthetic pigments and microscopic cell counts require relatively large sample volumes ( 1000 $\mathrm{ml}$ and 50 to $100 \mathrm{ml}$, respectively). In more recent studies (C. E. Hare \& D. A. Hutchins unpubl. data), we have used overnight outflow sampling to gain further insight into changes in the community over time using both microscopic cell counts and pigment analysis.

Total cyanobacteria (both Synechococcus and Prochlorococcus) decreased throughout the experiment from Day 1 in all treatments, although Synechococcus remained the numerically dominant group in the lowest iron treatment. Large eukaryotes $(>5 \mu \mathrm{m})$ did not immediately respond, but slowly increased for the first 3 days. On Day 2, nanoplankton (2 to $5 \mu \mathrm{m}$ ) appeared to be the first to respond to the addition of iron in the higher 2 treatments. However these cells then declined somewhat, possibly due to the effects of protozoan grazing in the bottles. This conclusion was supported by the increases in phaeopigments seen in 
the bottles; the increase in phaeophytin $b$ especially suggests that grazing was a major factor in the decline of Prochlorococcus seen in the bottles. Total heterotrophic bacterial numbers increased by an order of magnitude on Day 4 following this decline of nanoplankton cell abundance. Analysis of pigment concentrations on the final day also suggested that the cyanobacteria decreased throughout the 5 days while diatoms and prymnesiophytes increased in all treatments, similar to the parallel growout experiments (Hutchins et al. 2002). Final levels of diatom and prymnesiophyte pigments were highest and roughly equivalent in the 2 highest Fe treatments, but were lower in the $0.8 \mathrm{nM}$ bottles.

Eldridge et al. (2004) used growout experiments in the Peru upwelling area to show that the relative size of nanoplankton (picoeukaryotes) decreased with increasing iron stress. They suggested that the increased competitive success of nanoplankton at lower iron concentrations over larger eukaryotes could be due to miniaturization. We found in our study that increases in small continuous inputs of Fe instead may have led to a smaller nanoplanktonic community. The differences in the response of cell size within a single size class between these 2 experiments could be due to the differing methods of iron input, or the range of iron concentrations added or 'removed' (see Eldridge et al. 2004). The slight increase in size with decreasing iron in our study was over a small range of iron concentration, while the major decrease in size found in the growout experiments was documented between highest added iron concentrations (2 nM) and desferrioxamine $\mathrm{B}$ additions ( $5 \mathrm{nM}$ 'Fe removed', Eldridge et al. 2004).

Turpin \& Harrison (1980) found that patchiness (pulses versus continuous) in the addition of limiting nutrients could have effects both on the competitive advantage of species, and on the cell size of diatom species. Our results and those of Eldridge et al. (2004) indicate that the ways in which phytoplankton groups adapt to changing iron inputs and changes in cell size may also be regulated by the mode of Fe input. For example, adaptation processes may differ after a large single Fe pulse due to an aeolian input or storm mixing, versus new supplies from slow continuous upwelling over days or weeks. Future experiments should study size changes within different algal groups to gain insight into taxon-specific responses to differing Fe and nutrient regimes.

Ratios of particulate nutrients are greatly influenced by changing iron concentrations in many growout experiments (Takeda \& Obata 1995, Hutchins \& Bruland 1998, Hutchins et al. 1998, 2002, Firme et al. 2003). Our study confirms this result, but suggests that input processes and resulting community structure changes may greatly influence the extent of change in the ratios. Elemental ratios of $\mathrm{BSi}: \mathrm{PON}$ in both the parallel growout and this study increased from around 0.2 to 0.3 in the initial community to close to 1.0 with increasing iron concentrations. The latter ratio is typical of diatoms growing under Fe-replete conditions (Brzezinski 1985). The initial low BSi:PON ratio was likely due to the low abundance of diatoms in the community, which was dominated by cyanobacteria. The diatoms that were present were mostly small, less silicified pennate species rather than the large, heavily silicified centric diatoms found in studies in other coastal upwelling regions like California (Hutchins \& Bruland 1998, Hutchins et al. 1998).

In contrast to many previous experiments in other regions, BSi:PON production ratios in our experiments were not higher in the low Fe treatment but rather were greatly increased in both of the higher iron treatments. This effect was due to a strong community shift from non-silicified algae towards diatoms with increasing iron. In previous experiments in the California upwelling region showing higher $\mathrm{Si} / \mathrm{N}$ production ratios in controls, both the controls and Fe-additions were consistently dominated by diatoms (Hutchins et al. 1998, Firme et al. 2003, Franck et al. 2003). The greater increase in $\mathrm{BSi}$ relative to $\mathrm{PON}$ in our Peru experiments supports the 'silicate pump' scenario in which $\mathrm{N}$ is recycled more efficiently than Si (Dugdale et al. 1995).

The shifts in the phytoplankton community in this experiment were similar to the trends seen in mesoscale fertilization experiments (IronEx II, Coale et al. 1996a, and the Southern Ocean Iron RElease Experiment [SOIREE], Boyd 2000). Picophytoplankton and pico-prokaryotes in IronEx II (Cavender-Bares et al. 1999) and picoeukaryotes in SOIREE (Gall et al. 2001) were the first to respond to increasing Fe-additions. We saw a similar trend, with an initial transient response by small nanoeukaryotes. Also, iron stress on the community was reduced within $24 \mathrm{~h}$ in our continuous culture (as indicated by increased $F_{\mathrm{v}} / F_{\mathrm{m}}$ ), as in the open ocean experiments. However, $F_{\mathrm{v}} / F_{\mathrm{m}}$ continued to increase over the first 5 days in our study, unlike the IronEx II unenclosed fertilization experiments in nearby Equatorial Pacific waters where there was a marked decrease after Day 4 (Behrenfeld et al. 1999).

After the initial response by the picophytoplankton, diatoms in most previous open ocean experiments became dominant, as in this study. This is most likely due to a combination of increased iron availability, and grazing pressure on smaller cells by microzooplankton. Chl a concentration in this study remained low (1.5 $\mathrm{mg} \mathrm{chl} \mathrm{a}^{-1}$ in the highest iron treatment) similar to the values seen in fertilization experiments. Boyd (2002) suggested that the SOIREE bloom acted as 
a 'chemostat', exchanging with and entraining surrounding HNLC waters. Thus, our shipboard continuous culturing design may have mimicked some of the exchange processes that occur between fertilized water parcels and the surrounding HNLC water in open ocean iron experiments.

However, in the experiments presented here our continuous culturing method is not a true chemostat, but only an approximation. Steady-state was never reached for nutrients or biomass due to the short experimental timeframe, intermittent shaking, and sampling perturbations that caused up to a $10 \%$ difference in dilution rates. The natural light/dark cycle used for the incubations also means that that culture system could more accurately be termed a cyclostat (Rhee et al. 1981). Despite these limitations, this method has the potential to simulate short-term (d) continuous delivery of nutrients from below in a manner not possible with any other perturbation technique now in use. The limitations and advantages of this method are discussed further in Hutchins et al. (2003).

Our experimental design allowed the incorporation of 2 loss terms: direct grazing on small cells by micrograzers, and losses of both large and small species in the outflow. Micrograzers were present in the bottles, but as with most shipboard experiments larger grazers like copepods were not well represented during water collection. The outflow of incubation water in the continuous culturing design helps to simulate natural loss terms such as advection, sinking and grazing on all phytoplankton size classes, in contrast to growout experiments in which large cells are not removed at all. Nevertheless, as in all shipboard experiments, in the continuous culture system larger species may enjoy an artificial advantage because no appreciable macrograzing occurs in the bottles.

\section{CONCLUSIONS}

We conclude that the shipboard continuous culturing system presented by Hutchins et al. (2003) can be adapted and effectively used in conjunction with TMC methodology to examine iron-driven changes in the phytoplankton community and biogeochemistry in HNLC areas. Variations in iron supply rates due to upwelling can be simulated through low continuous additions, and this method is unique in that iron can be added already bound to natural ligands found in the seawater during collection. Loss terms such as grazing, export and dilution are also simulated to some extent, because cells are continuously removed through the outflow. This alternative experimental method avoids the high costs of mesoscale fertilizations and some of the artifacts associated with growout experiments. It can also be used to examine questions that neither of these methods can address, such as the effect of variation in realistic iron supply rates and concentrations on phytoplankton community composition and nutrient and carbon cycling.

Acknowledgements. The authors thank the captain and crew of the RV 'Melville', G. J. Smith, M. B. Alm, S. F. Riseman and Y. Zhang. Grant support was provided by NSF OCE 9811062 and 0094535 to D.A.H., NSF OCE 9811114 and 0137085 to K.W.B., NSF OCE 9907931 to G.R.D., NSF OCE 9977040 to S.W.W. and CEBIC to C.G.T.

\section{LITERATURE CITED}

Behrenfeld MJ, Falkowski PG (1999) Widespread Fe limitation of phytoplankton in the Southern Pacific Ocean. Science 283:840-843

Behrenfeld MJ, Bale AJ, Kobler ZS, Falkowski PG (1996) Confirmation of iron limitation of phytoplankton photosynthesis in the equatorial Pacific Ocean. Nature 383: 508-511

Blasco D, Estrada M, Jones B (1980) Relationship between the phytoplankton distribution and composition and the hydrography in the northwest African upwelling region near Cabo Corbeiro. Deep-Sea Res A 27:799-821

Boyd PW (2002) The role of iron in the biogeochemistry of the Southern Ocean and equatorial Pacific: a comparison of in situ iron enrichments. Deep-Sea Res II 49:1803-1821

Boyd PW, Watson AJ, Law CS, Abraham ER and 31 others (2000) A mesoscale phytoplankton bloom in the polar Southern Ocean stimulated by iron fertilization. Nature 407:695-702

Boyd PW, Law CS, Wong CS, Nojiri Y and 34 others (2004) The decline and fate of an iron-induced subarctic phytoplankton bloom. Nature 428:549-553

Brand LE (1991) Minimum iron requirements of marine phytoplankton and the implications for the biogeochemical control of new production. Limnol Oceanogr 36: 1756-1771

Bruland KW, Donat JR, Hutchins DA (1991) Interactive influences of bioactive trace-metals on biological production in oceanic waters. Limnol Oceanogr 36:1555-1577

Bruland KW, Rue EL, Smith GJ (2001) Iron and macronutrients in California coastal upwelling regimes: implications for diatom blooms. Limnol Oceanogr 46:1661-1674

Bruland KW, Rue EL, Smith GJ, DiTullio GR (2005) Iron, macronutrients and diatom blooms in the Peru Upwelling regime: brown and blue waters of Peru. Mar Chem 93: 81-103

Brzezinski MA (1985) The Si:C:N ratio of marine diatoms: interspecific variability and the effect of some environmental variables. J Phycol 21:347-357

Brzezinski MA, Nelson DM (1995) The annual silica cycle in the Sargasso Sea near Bermuda. Deep-Sea Res I 42: 1215-1237

Campbell L (2001) Flow cytometric analysis of autotrophic picoplankton. Methods Microbiol 30:317-343

Cavender-Bares KK, Mann EL, Chisholm SW, Ondrusek ME, Bidigare RR (1999) Differential response of equatorial Pacific phytoplankton to iron fertilization. Limnol Oceanogr 44:237-246

Coale KH, Johnson KS, Fitzwater SE, Gordon RM and 15 others (1996a) A massive phytoplankton bloom induced 
by an ecosystem-scale iron fertilization experiment in the equatorial Pacific Ocean. Nature 379:621-624

Coale KH, Fitzwater SE, Gordon RM, Johnson KS, Barber RT (1996b) Control of community growth and export production by upwelled Fe in the equatorial Pacific. Nature 383: 495-501

Coale KH, Johnson KS, Chavez FP, Buesseler KO and 44 others (2004) Southern Ocean iron enrichment experiment: carbon cycling in high- and low-Si waters. Science 304:408-414

Codispoti LA, Dugdale RC, Minas HJ (1982) A comparison of the nutrient regimes off northwest Africa, Peru and Baja California. Rapp P R Cons Int Explor Mer 180:184-201

de Baar JHW, Buma AGJ, Nolting RF, Cadee GC, Jacques G, Treguer PJ (1990) On Fe limitation of the Southern Ocean: experimental observations in the Weddell and Scotia Seas. Mar Ecol Prog Ser 65:105-122

de Baar JHW, Dejong JTM, Bakker DCE, Loscher BM, Veth C, Bathmann U, Smetacek V (1995) Importance of iron for plankton blooms and carbon-dioxide drawdown in the Southern Ocean. Nature 373:412-415

de Mendiola BR (1981) Seasonal phytoplankton distribution along the Peruvian coast. In: Richards FA (ed) Coastal upwelling. American Geophysical Union, Washington, DC, p 348-356

DiTullio GR, Geesey ME (2002) Photosynthetic pigments in marine algae and bacteria. In: Bitton G (ed) The encyclopedia of environmental microbiology. John Wiley \& Sons, New York, p 2453-2470

DiTullio GR, Geesey ME, Jones DR, Daly KL, Campbell L, Smith WO Jr (2003) Phytoplankton assemblage structure and primary productivity along $170^{\circ} \mathrm{W}$ in the South Pacific Ocean. Mar Ecol Prog Ser 255:55-80

DiTullio GR, Geesey ME, Maucher JM, Alm MB, Riseman SF, Bruland KW (in press) Influence of iron on algal community composition and physiological status in the Peru Upwelling System. Limnol Oceanogr

Dugdale RC, Wilkerson FP, Minas HJ (1995) The role of a silicate pump in driving new production. Deep-Sea Res I 42:697-719

Durand MD, Olson RJ (1996) Contributions of phytoplankton light scattering and cell concentration changes to diel variations in beam attenuation in the equatorial Pacific from flow cytometric measurements of pico-, ultra- and nanoplankton. Deep-Sea Res II 43:891-906

Eldridge ML, Trick CG, Alm M, DiTullio GR, Rue EL, Bruland KW, Hutchins DA, Wilhelm SW (2004) Phytoplankton community response to a manipulation of bioavailable iron in HNLC waters of the subtropical Pacific Ocean. Aquat Microb Ecol 35:79-91

Estrada M, Blasco D (1979) Two phases of the phytoplankton community in the Baja California upwelling. Limnol Oceanogr 24:1065-1080

Firme GF, Bruland KW, Rue EL, Weeks DA, Hutchins DA (2003) Spatial and temporal variability in phytoplankton iron limitation along the California coast and consequences for $\mathrm{Si}, \mathrm{N}$ and $\mathrm{C}$ biogeochemistry. Global Biogeochem Cycles 17:(1), 1016, doi: 10.1029/2001 GB001824

Franck VM, Bruland KW, Hutchins DA, Brzezinski MA (2003) Iron and zinc effects on silicic acid and nitrate uptake kinetics in three high-nutrient, low chlorophyll (HNLC) regions. Mar Ecol Prog Ser 252:15-33

Frankel SL, Binder BJ, Chisholm SW, Sharpiro HM (1990) A high-sensitivity flow cytometer for studying picoplankton. Limnol Oceanogr 35:1164-1169

Gall MP, Boyd PW, Hall J, Safi KA, Chang H (2001) Phytoplankton processes. Part 1. Community structure during the Southern Ocean Iron RElease Experiment (SOIREE). Deep-Sea Res II 48:2551-2570

Gervais F, Riebesell U, Gorbunov MY (2002) Changes in primary productivity and chlorophyll $a$ in response to iron fertilization in the Southern Polar Frontal Zone. Limnol Oceanogr 47:1324-1335

Gledhill M, van den Berg CMG (1994) Determination of complexation of iron (III) with natural organic complexing ligands in seawater using cathodic stripping voltammetry. Mar Chem 47:41-54

Harrison PJ, Davis CO (1979) The use of outdoor phytoplankton continuous cultures to analyze factors influencing species selection. J Exp Mar Biol Ecol 41:9-23

Harrison PJ, Turpin DH (1982) The manipulation of physical, chemical, and biological factors to select species from natural phytoplankton communities. In: Grice GD, Reeve MR (eds) Marine mesocosms: biological and chemical research in experimental ecosystems. Springer-Verlag, New York, p 275-289

Hobbie JE, Daley RJ, Jasper S (1977) Use of nuclepore filters for counting bacteria by fluorescence microscopy. Appl Environ Microbiol 33:1225-1228

Hutchins DA, Bruland KW (1998) Iron-limited diatom growth and $\mathrm{Si}: \mathrm{N}$ uptake ratios in a coastal upwelling regime. Nature 393:561-564

Hutchins DA, DiTullio GR, Zhang Y, Bruland KW (1998) An iron limitation mosaic in the California upwelling regime. Limnol Oceanogr 43:1037-1054

Hutchins DA, Franck VM, Brzezinski MA, Bruland KW (1999a) Inducing phytoplankton iron limitation in ironreplete coastal waters with a strong chelating ligand. Limnol Oceanogr 44:1009-1018

Hutchins DA, Witter AE, Bulter AE, Luther GW III (1999b) Competition among marine phytoplankton for different chelated iron species. Nature 400:858-861

Hutchins DA, Sedwick PN, DiTullio GR, Boyd PW, Grifiths B, Queguiner B, Crossley C (2001) Fe and silicic acid limitation of phytoplankton growth in the subantarctic Southern Ocean: experimental results from the SAZ project. J Geophys Res C 106:559-572

Hutchins DA, Hare CE, Weaver RS, Zhang Y and 11 others (2002) Phytoplankton iron limitation in the Humboldt Current and Peru Upwelling. Limnol Oceanogr 47:997-1011

Hutchins DA, Pustizzi F, Hare CE, DiTullio GR (2003) A shipboard natural community continuous culture system for ecologically relevant low-level nutrient enrichment experiments. Limnol Oceanogr Methods 1:82-91

Johnson KS, Chavez FP, Friederich GE (1999) Continentalshelf sediment as a primary source of iron for coastal phytoplankton. Nature 398:697-700

Kolber ZS, Prasil O, Falkowski PG (1998) Measurements of variable chlorophyll fluorescence using fast repetition rate techniques: defining methodology and experimental protocols. Biochem Biophys Acta 1367:88-106

Landry MR, Barber RT, Bidigare RR, Chai F and 9 others (1997) Iron and grazing constraints on primary production in the central equatorial Pacific: an EqPac synthesis. Limnol Oceanogr 42:405-418

Martin JH, Gordon RM (1988) Northeast Pacific iron distributions in relation to phytoplankton productivity. Deep-Sea Res A 35:177-196

Martin JH, Gordon RM, Fitzwater S (1990) Iron in Antarctic waters. Nature 345:156-158

Martin JH, Gordon RM, Fitzwater SE (1991) The case for iron. Limnol Oceanogr 36:1793-1802

Martin JH, Coale KH, Johnson KS, Fitzwater SE and 40 others (1994) Testing the iron hypothesis in ecosystems of the 
equatorial Pacific Ocean. Nature 371:123-129

Mickelson MJ, Maske H, Dugdale RC (1979) Nutrient-determined dominance in multispecies chemostat cultures of diatoms. Limnol Oceanogr 24:298-315

Noble RT, Fuhrman JA (1998) Use of SYBR Green I for rapid epifluorescence counts of marine viruses and bacteria. Aquat Microb Ecol 14:113-118

Price NM, Andersen LF, Morel FMM (1991) Iron and nitrogen nutrition of equatorial Pacific plankton. Deep-Sea Res 38: 1361-1378

Rhee GY, Gotham IJ, Chisholm SW (1981) Use of Cyclostat cultures to study phytoplankton ecology. In: Calcott P (ed) Continuous cultures of cells. CRC Press, Boca Raton, FL, p 159-186

Riseman SF, DiTullio GR (2004) Particulate dimethylsulfoniopropionate and dimethylsulfoxide in relation to iron availability and algal community composition structure in the Peru upwelling system. Can J Fish Aquat Sci 61: 721-735

Rue EL, Bruland KW (1995) Complexation of iron(III) by natural organic ligands in the Central North Pacific as determined by a new competitive ligand equilibrium/absorptive cathodic stripping voltammetric method. Mar Chem 50:117-138

Rue EL, Bruland KW (1997) The role of organic complexation on ambient iron chemistry in the equatorial Pacific Ocean and the response of a mesoscale iron addition experiment. Limnol Oceangr 42:901-910

Strom SL, Morello TA, Bright KJ (1998) Protozoan size influences algal pigment degradation during grazing. Mar Ecol Prog Ser 164:189-197

Takeda S, Obata H (1995) Response of equatorial Pacific phytoplankton to subnanomolar $\mathrm{Fe}$ enrichment. Mar Chem 50:219-227

Thomas WH, Pollock M, Seibert DLR (1980) Effects of simulated upwelling and oligotrophy on chemostat-grown natural marine phytoplankton assemblages. J Exp Mar Biol Ecol 45:25-36

Tilman D (1977) Resource competition between planktonic

Editorial responsibility: Paul Harrison,

Kowloon, Hong Kong algae: an experimental and theoretical approach. Ecology $58: 338-348$

Titman D (1976) Ecological competition between algae: experimental conformation of resource-based competition theory. Science 192:463-465

Trick CG, Wilhelm SW (1995) Physiological-changes in the coastal marine cyanobacterium Synechococcus sp. PCC7002 exposed to low ferric ion levels. Mar Chem 50:207-217

Tsuda A, Takeda S, Saito H, Nishioka J and 22 others (2003) A mesoscale iron enrichment in the western Subarctic Pacific induces a large centric diatom bloom. Science 300: 958-961

Turpin DH, Harrison PJ (1979) Limiting nutrient patchiness and its role in phytoplankton ecology. J Exp Mar Biol Ecol 39:151-166

Turpin DH, Harrison PJ (1980) Cell size manipulation in natural marine, planktonic, diatom communities. Can J Fish Aquat Sci 37:1193-1195

Turpin DH, Parslow JS, Harrison PJ (1981) On limiting nutrient patchiness and phytoplankton growth: a conceptual approach. J Plankton Res 3:421-431

Wells ML (2003) The level of iron enrichment required to initiate diatom blooms in HNLC waters. Mar Chem 82: 101-114

Welschmeyer NA (1994) Fluorometric analysis of chlorophyll $a$ in the presence of chlorophyll $b$ and phaeopigments. Limnol Oceanogr 39:1985-1992

Wilhelm SW, Trick CG (1995) Physiological profiles of Synechococcus (Cyanophyceae) in iron-limiting continuous cultures. J Phycol 31:79-85

Wu JF, Luther GW (1995) Complexation of Fe(III) by natural organic-ligands in the northwest Atlantic Ocean by a competitive ligand equilibration method and a kinetic approach. Mar Chem 50:159-177

Zapata M, Rodriguez F, Garrido JL (2000) Separation of chlorophylls and carotenoids from marine phytoplankton: a new HPLC method using a reversed phase $\mathrm{C}_{8}$ column and pyridine-containing mobile phases. Mar Ecol Prog Ser 195:29-45

Submitted: August 25, 2004; Accepted: December 11, 2004

Proofs received from author: March 7, 2005 